\title{
Study of cephalic index in Southern Odisha Population
}

\author{
Dr Sunita Patro ${ }^{1}$, Dr Ramkristna Sahu ${ }^{2}$, Dr Sadananda Rath ${ }^{3}$ \\ ${ }^{I}$ (Post Graduate Student of Department of Anatomy, M.K.C.G. Medical College, Berhampur, Odisha, India) \\ ${ }^{2}$ (Associate Professor, Department of Anatomy, M.K.C.G. Medical College, Berhampur, Odisha, India) \\ ${ }^{3}$ Professor and Head of Department of Anatomy, M.K.C.G. Medical College, Berhampur, Odisha, India)
}

\begin{abstract}
Morphology of all living beings undergo changes in varying degrees during their life and the features are variable in the individuals of the same species. No two persons are similar in their measurable character. Previewing the various works on the cephalic index and observing the socio-cultural uniqueness of southern odisha this study was done to find out the distribution of the cephalic index in the population of southern odisha. This study was carried out on 1030 outdoor patients of different parts of southern Odisha. Maximum head length and maximum head breadth were recorded using the spreading callipers. Cephalic indices were calculated using the formula (Maximum head breadth/Maximum head length) x 100. Basing these indices the head shapes were classified as dolicocephalic, mesocephalic, brachycephalic and hyperbrachycephalic. From this study it was observed that mean cephalic index in females is higher than that of males. In males, maximum were mesocephalics followed by dolicephalics but in females, maximum were mesocephalics followed by brachycephalics. The data of the present study may be useful for forensic medicine experts, plastic surgeons, anatomists, anthropologists, oral surgeons, for clinical and in research studies.
\end{abstract}

\section{Introduction}

Morphology of all living beings undergo changes in varying degrees during their life and the features are variable in the individuals of the same species. No two persons are similar in their measurable character. Anthropometry evolved as a standard scientific technique for measuring human body dimensions ${ }^{1}$. Human body dimensions are affected by ecological, geographical, racial, gender and age factors ${ }^{2,3}$. On the basis of above factors, anthropometric studies are conducted on the age, sex, caste and racial groups in certain geographical zones $^{4,5}$.

Cephalometry pertains to be the most versatile technique in the investigation of the craniofacial skeleton, because of its simplicity, acceptability and practicality ${ }^{6,7}$. Cephalic index used as a useful anthropological tool for analysis of racial differences in a population and also to ascertain sexual dimorphism. Comparison of changes in cephalic index between parents, offsprings and siblings can give information about the genetic transmission of the inherited characters ${ }^{8,9}$ The relevant data on cephalic index of a population is very much essential in designing various orthopaedic and physiotherapic equipments of head and face like cranial remodelling band(helmet), head phones, goggles etc by formulating standard sizes ${ }^{10}$.

Regarding the effect of racial, ethnic and geographical factors on head dimensions, the present study was designed to elucidate the norms of cephalic indices, the types of head shapes and sexual dimorphism in Southern Odisha population.

\section{Material And Method}

In the present work, 1030 outdoor patients of M.K.C.G. Medical college and Hospital, Berhampur Odisha of age $\geq 18$ years coming from different parts of southern Odisha, were selected as subjects. Study was carried out with ethical committee clearance. All measurements were taken after obtaining written consent. Any subject who had any obvious physical deformity, craniofacial trauma \& obstructive hairstyle affecting the results was excluded from the study.

The anatomical landmarks i.e. glabella, inion and euryon were marked. The anatomical landmarks were defined as fallows :

Glabella : A point above the nasal root between the eyebrows and intersected by mid-sagittal plane.

Inion: The distal most point placed on the external occipital protuberance in the mid-sagittal plane.

Euryon: The lateral most point placed on the side of the head.

All the measurements were taken with the subject sitting in chair, in relaxed condition \& the head in the anatomical position. The method used for assessing cranial index was Hrdlicka's method ${ }^{11}$. The maximum head length was measured as the maximum antero-posterior diameter by spreading callipers from glabella to inion. The maximum head breath was measured as the maximum transverse diameter between two euryons using spreading callipers. All measurements were taken in centimetres and to an accuracy of 0.10.The cephalic indices were calculated by multiplying the head breadth with 100 and dividing it with the head length. Depending upon these indices the types of head shapes were classified as given by Williams et al, $1995^{12}$. 
Study of cephalic index in Southern Odisha Population

\begin{tabular}{|l|l|l|}
\hline SERIAL NO. & HEAD SHAPE & CEPHALIC INDEX RANGE \\
\hline 1 & Dolicocephalic & $<74.9$ \\
\hline 2 & Mesocephalic & $75.0---79.9$ \\
\hline 3 & Brachicephalic & $80.0---84.9$ \\
\hline 4 & Hyperbrachicephalic & $85.0---89.9$ \\
\hline
\end{tabular}

Statistical Analysis: The data was analysed by Microsoft Excel and all the statistical tests and calculations were performed using the software Graph-pad Prism Version 5. From the observations of the present study the parametric data were analysed using unpaired ' $t$ ' test (for two unmatched population). The nonparametric data (number of subjects) were analysed by chi-square test to find the association ${ }^{13}$.

\section{Observations And Results}

From the collected data, the mean values and standard deviation (SD) were calculated for maximum head length (MHL), maximum head breadth (MHB) and cephalic index (C.I.). The summary of the results of these parameters are presented in Table 1 and 2. Comparison of cephalic index with other population was presented in Table -3.

TABLE - 1 Gender distribution of Maximum Head Length, Maximum Head Breadth and Cephalic indices in population studied

\begin{tabular}{|l|l|l|l|l|l|}
\hline SI. No. & \multirow{2}{*}{ Sex } & \multirow{2}{*}{ No. } & Mean \pm SD & C.I \\
\cline { 4 - 6 } & & & MHL(cm) & MHB(cm) & $77.28 \pm 3.22$ \\
\hline 1. & Male & 610 & $19.5 \pm 1.14$ & $15.09 \pm 0.94$ & $78.38 \pm 3.77$ \\
\hline 2. & Female & 420 & $19.16 \pm 1.53$ & $15 \pm 1.28$ & \multicolumn{2}{l}{} \\
\hline
\end{tabular}

Figure-1

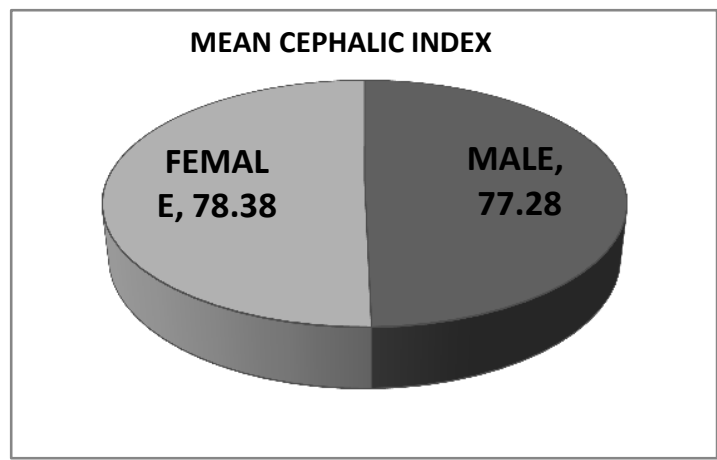

Figure-3

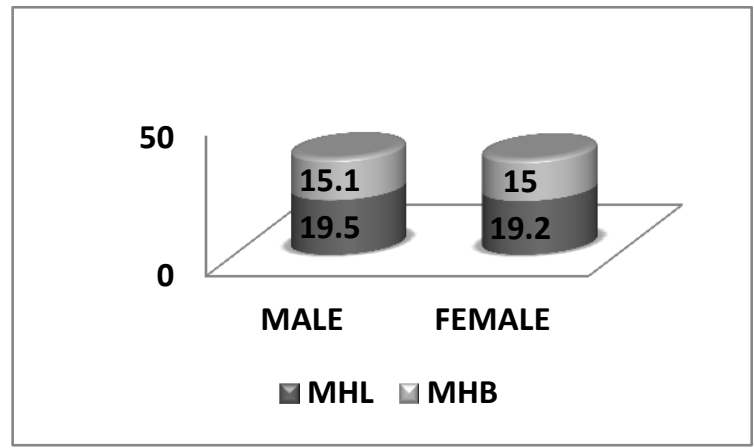

TABLE - 2 Distribution of different head shapes in different gender groups

\begin{tabular}{|l|l|l|l|l|l|l|}
\hline Sl. No. & Gender Group & Dolicocephalic & Mesocephalic & Brachycephalic & $\begin{array}{l}\text { Hyper } \\
\text { Brachycephalic }\end{array}$ & Row total \\
\hline 1. & Male & $\begin{array}{l}117 \\
(19.18 \%)\end{array}$ & $\begin{array}{l}411 \\
(67.37 \%)\end{array}$ & $\begin{array}{l}71 \\
(11.64 \%)\end{array}$ & $\begin{array}{l}11 \\
(1.80 \%)\end{array}$ \\
\hline 2. & Female & $\begin{array}{l}84 \\
(20 \%)\end{array}$ & $\begin{array}{l}194 \\
(46.19 \%)\end{array}$ & $\begin{array}{l}134 \\
(31.90 \%)\end{array}$ & $\begin{array}{l}8 \\
(1.90 \%)\end{array}$ \\
\hline
\end{tabular}

Figure-3

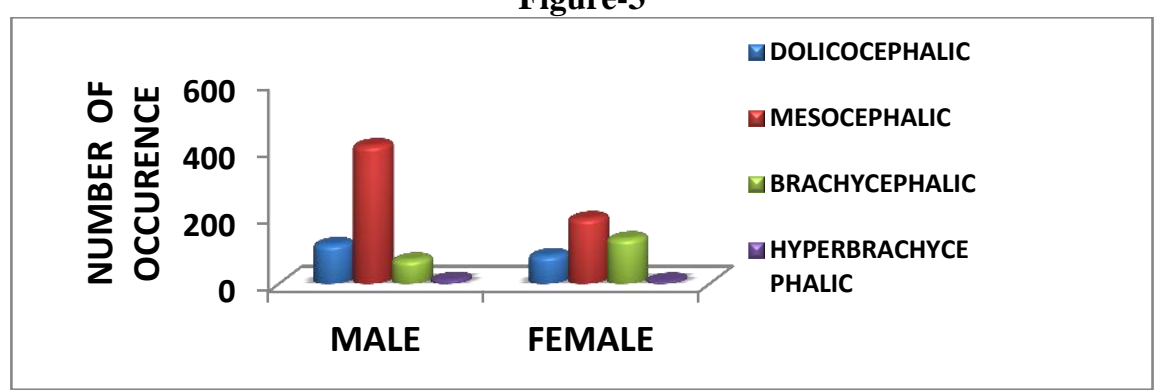


The mean cephalic index of Southern Odisha population was 77.75 \pm 3.44 . The mean cephalic index for male was $77.28 \pm 3.22$ and for female was $78.38 \pm 3.77$. The difference between male and female mean cephalic index was significant $(\mathrm{p}<0.001)$. Similarly, the mean head length and mean head breadth for male were 19.5 \pm 1.14 and 15.09 \pm 0.94 . The head length and head breadth for female were $19.16 \pm 1.53$ and $15 \pm 1.28$. The difference between male and female head length was highly significant $(p<0.001)$ but the difference between male and female head breadth was not significant $(\mathrm{p}>0,05)$.

\section{Discussion}

The variations in cephalic indices between and within the population had been attributed to a complex interaction between genetics and environmental factors. Study of cephalic index was done by various workers among different gender groups of the world as follows:

TABLE - 3

\begin{tabular}{|c|c|c|c|}
\hline $\begin{array}{l}\text { Sl. } \\
\text { No }\end{array}$ & Name of Workers & Population Studied & Mean Cephalic Index \\
\hline \multirow[t]{2}{*}{1.} & \multirow[t]{2}{*}{ Oladipo and Olotu, $2006^{14}$} & Ijaw males & 80.98 \\
\hline & & Ijaw females & 78.24 \\
\hline \multirow[t]{2}{*}{2.} & \multirow[t]{2}{*}{ Oladipo and Olotu, $2006^{14}$} & Igbo males & 79.04 \\
\hline & & Igbo females & 76.83 \\
\hline \multirow[t]{2}{*}{3.} & \multirow[t]{2}{*}{ Oladipo and Olotu, $2009^{15}$} & Ogonis males & 111.18 \\
\hline & & Ogonis females & 75.09 \\
\hline \multirow[t]{2}{*}{4.} & \multirow[t]{2}{*}{ Odokuma et al, $2010^{16}$} & West African males & 77.67 \\
\hline & & West African females & 78.14 \\
\hline \multirow[t]{2}{*}{5.} & \multirow[t]{2}{*}{ Ilayperuma I, $2011^{17}$} & Srilankan males & 78.04 \\
\hline & & Srilankan females & 79.32 \\
\hline \multirow[t]{2}{*}{6.} & \multirow[t]{2}{*}{ Anitha et al, $2011^{18}$} & North Indian males & 79.14 \\
\hline & & North Indian females & 80.74 \\
\hline \multirow[t]{2}{*}{7.} & \multirow[t]{2}{*}{ Yogain V K et al, $2012^{19}$} & Indian students males & 77.92 \\
\hline & & Indian students females & 80.85 \\
\hline \multirow[t]{2}{*}{8.} & \multirow[t]{2}{*}{ Mahesh Kumar et al, $2012^{20}$} & Haryanvi males & 66.72 \\
\hline & & Haryanvi females & 72.25 \\
\hline \multirow[t]{2}{*}{9.} & \multirow[t]{2}{*}{ Ila Jitesh Gujaria et al, $2012^{21}$} & Marathi males & 77.08 \\
\hline & & Marathi females & 79.02 \\
\hline \multirow[t]{2}{*}{10.} & \multirow[t]{2}{*}{ Ila Jitesh Gujaria et al, $2012^{21}$} & Andhra males & 76.28 \\
\hline & & Andhra females & 78.16 \\
\hline \multirow[t]{2}{*}{11.} & \multirow[t]{2}{*}{ Ila Jitesh Gujaria et al, $2012^{21}$} & Gujarati males & 80.42 \\
\hline & & Gujarati females & 81.20 \\
\hline \multirow[t]{2}{*}{12.} & \multirow[t]{2}{*}{ Present study, 2013} & Southern Odisha males & 77.28 \\
\hline & & Southern Odisha females & 78.38 \\
\hline
\end{tabular}

In the present study, the mean cephalic index in males was 77.28 and in females 78.38. The result of our study was almost nearer to study on Andhra males and females by Ila Jitesh Gujaria et al, 2012 in which the mean cephalic index in males was 76.28 and in females $78.16^{21}$. The dominant type of head shape in male was mesocephalic $(67.37 \%)$ followed by dolicocephalic $(19.18 \%)$,brachycephalic and hyperbrachycephalic whereas in female the dominant type of head shape was mesocephalic $(46.19 \%)$ followed by brachycephalic $(31.90 \%)$, dolicocephalic and hyperbrachycephalic. The finding of our study i.e. mesocephalic dominant head shape both in males and females was similar to study done on Andhra males and females by Ila Jitesh Gujaria et al, $2012^{21}$ and Srilankan males and females by Ilayperuma I, $2011^{17}$ in which mesocephalic was the dominant head shape. The similar studies were conducted in different groups and cephalic index was found to be different for different groups due to genetic and geographical factors.

\section{Conclusion}

In Southern Odisha population, the mean cephalic index in males was 77.28 and in females 78.38. The dominant head shape was mesocephalic in both sexes i.e. in males (67.37\%) and in females (46.19\%). The observations and results of this study may provide platform for similar extended cephalometric studies based on various communities/ castes/ races of particular geographical zones.

\section{References}

[1]. Eickstedt E.V. The races and types of the western Himalayas. Map in India. 1926; 6: 237.

[2]. Imami-Mibodi MA and Mastri-Frahani R. Study of normal range of anatomical dimensions of one-day old newborn by cephalometry. J Med Council Islamic Republic of Iran.1996; 14: 1-8.

[3]. Afak SY and Turgut HB. Weight,length.head and face measurements in Turkish newborns of central Anatolia. Gaji Medical Journal.1998;9: 116-120.

[4]. Del Sol M. Cephalic index in a group of mapuche individuals in the IX Region of Chile. Int. Jr. Morphology, 2005; 23(3):241-246.

[5]. Golalipur et al. The shapes of head and face in normal female newborns in south-east of Caspian sea (Iran-Gorgan). Eur. Jr. Anat. 2005;9(2):95-98. 
[6]. Agron Rexhepi and Vjollca Meka. Cephalofacial morphological characteristics of Albanian Kosova population. Int. Jr. of morphology, 2008; 26(4):935-940.

[7]. Grant TM and Peter AM. Size and shape measurement in contemporary cephalometrics. Eur. Jr. of Orthodontics, 2003; 25(3):231 242.

[8]. Shah GV, Jadhav HR.The study of cephalic index in students of Gujrat. J Anat Soc India. 2004; 53(1):1-12.

[9]. Rabey GP. Craniofacial morphoanalysis. Proc. R. Soc. Med. 1971; 64:103-111.

[10]. Singh P, Purkit R. A cephalometric study among subcaste groups Dangi and Ahirwar of Khurai Block. Anthropol. 2006: 8(3): 21517.

[11]. Hrdlika Practical Anthropometry. $4^{\text {th }}$ Edition, Philadelphia. The Wistar institute of Anatomy and Biology, 1952:87-89.

[12]. William P, Dyson M, DussaakJ E, Bannister LH, Berry MM, Collins P, Ferguson MWJ. Gray's Anatomy. In: Skeletal system, 38 Edn. Elbs with Churchil Livingston, London, p 607-612(1995).

[13]. Mahajan BK. Textbook of biostatistics. $7^{\text {th }}$ Edition. 2012.

[14]. Oladipo, G.S. and E.J. Olotu. Anthropometric comparison of cephalic indices between the ijaw and igbo tribes. Global Jr. Pure appl. Sci., 2006; 12(1):137-138.

[15]. Oladipo GS, Olotu JE and Suleiman Y. Anthropometric studies of Cephalic indices of the Ogonis in Nigeria. Asian Journal of Medical Sciences. 2009; 1(2):15-17.

[16]. Odokuma, E.I.,Akpuaka, F. C.,Igbigbi, P. S., Otuaga, P.O. and Ejebe, D.Patterns of cephalic indices in three West African population. African Journal of Biotechnology.2010; 9(11):1658-1662.

[17]. Ilayperuma I. Evaluation of cephalic indices of Srilankan population: A clue for Racial and Sex diversity. Int. Jr. Morphol. 2011; 29(1):112-117.

[18]. Anitha. M.R, Vijayanath. V, Raju.G.M, Vijayamahantesh S.N. Cephalic Index of North Indian Population. Anatomica Karnataka. $2011 ; 5(1): 40-43$.

[19]. Yogain VK, Pai SR, Kalthur SG, Hemalatha I. Study of Cephalic index in Indian students. Int. Jr. Morphol. 2012; 30(1):125-129.

[20]. Kumar M. and Patnaik V.V. Gopichand. The study of cephalic index in Haryanvi population. Int. Jr. of Pure and Appl. Biosc. 2013; 1(3): 1-6.

[21]. Gujaria IJ, Salve VM. Comparison of Cephalic index of three states of India. Int. Jr. Pharma. Bio. Sci. 2012;3(4):1022-1031. 